\title{
Lean-Burn Natural Gas Engines: Challenges and Concepts for an Efficient Exhaust Gas Aftertreatment System
}

\author{
Patrick Lott ${ }^{1}$ (D) $\cdot$ Olaf Deutschmann ${ }^{1}$ (D) \\ Received: 3 July 2020 / Revised: 3 November 2020 / Accepted: 14 November 2020 / Published online: 2 December 2020 \\ (C) The Author(s) 2020
}

\begin{abstract}
High engine efficiency, comparably low pollutant emissions, and advantageous carbon dioxide emissions make lean-burn natural gas engines an attractive alternative compared to conventional diesel or gasoline engines. However, incomplete combustion in natural gas engines results in emission of small amounts of methane, which has a strong global warming potential and consequently makes an efficient exhaust gas aftertreatment system imperative. Palladium-based catalysts are considered as most effective in low temperature methane conversion, but they suffer from inhibition by the combustion product water and from poisoning by sulfur species that are typically present in the gas stream. Rational design of the catalytic converter combined with recent advances in catalyst operation and process control, particularly short rich periods for catalyst regeneration, allow optimism that these hurdles can be overcome. The availability of a durable and highly efficient exhaust gas aftertreatment system can promote the widespread use of lean-burn natural gas engines, which could be a key step towards reducing mankind's carbon footprint.
\end{abstract}

Keywords Catalyst reactivation $\cdot$ Emission control $\cdot$ Gas engines $\cdot$ Methane oxidation $\cdot$ Palladium $\cdot$ Reductive pulsing

\section{Introduction}

The continuous technological progress initiated by industrialization resulted in our modern globalized world with a society whose energy supply is mainly based on carbon-containing fossil resources like coal, oil, and natural gas. Combustion of these resources releases energy, but also leads to considerable pollutant emissions. While undesired side-products such as carbon monoxide $(\mathrm{CO})$, nitric oxide $\left(\mathrm{NO}_{x}\right)$, or particulate matter (PM) are toxic for mankind and environment, the main combustion product carbon dioxide $\left(\mathrm{CO}_{2}\right)$ is considered a key driver for global warming.

Since climate change is one of the most urgent issues of our modern society, ambitious targets for the reduction of global $\mathrm{CO}_{2}$ emissions have been formulated in recent years, which becomes particularly obvious in the case of future $\mathrm{CO}_{2}$

Olaf Deutschmann

deutschmann@kit.edu

Patrick Lott

patrick.lott@kit.edu

1 Institute for Chemical Technology and Polymer Chemistry (ITCP), Karlsruhe Institute of Technology (KIT), Engesserstr. 20,

76131 Karlsruhe, Germany requirements for light-duty vehicles. Europe, for instance, aims at reducing its $\mathrm{CO}_{2}$ emissions compared to 2020 by $37.5 \%$ by 2030 in the light-duty sector, while the USA strives for approximately $23 \%$ reduction in the same time frame $[1,2]$. Overall, the European aspirations for a climate-neutral economy, mobility and society are most ambitious, culminating in the goal to achieve net-zero greenhouse gas emissions by 2050 [1].

However, modern combustion engines are already highly optimized and further substantial reduction of fuel consumption is technologically more and more challenging, hence alternative approaches are mandatory. In this regard, replacement of conventional gasoline or diesel fuels by natural gas that consits mainly of methane $\left(\mathrm{CH}_{4}\right)$ seems an attractive solution. Since $\mathrm{CH}_{4}$ has the highest hydrogen-to-carbon ratio of all hydrocarbons, natural gas has a superior carbon balance resulting in advantageous $\mathrm{CO}_{2}$ emissions that oil-based fuels cannot outperform. In addition, besides small amounts of unburnt hydrocarbons, gas engines emit comparably low levels of toxic $\mathrm{CO}$ and only moderate amounts of $\mathrm{NO}_{x}$. All these aspects make gas engines a technology with outstanding potential on the way towards a modern and sustainable energy supply.

An upward tendency of the global natural gas production and an all-time production record of 3937 billion cubic meters in 2018 underscores the growing interest in natural gas as an energy source [3]. Already today, natural gas is widely used 
for both stationary and mobile applications, i.e., in combined heat and power (CHP) plants for energy production or as a fuel for heavy-duty vehicles (Fig. 1). A fast transition from a mainly diesel- and gasoline-based energy supply in the near future, especially in the on-road and marine sector, towards a natural gas-based system as illustrated in Fig. 1 may benefit from the fact that many countries already have an existing natural gas infrastructure. This is an essential prerequisite for a widespread usage within the next years. Although fossil sources currently represent the main feedstock for natural gas, promising alternative concepts like biomethane and power-to-gas technologies can open up a sustainable access to the highly valuable energy source methane. In addition, such carbon-neutral approaches terminate gas emissions that typically occur during the production of fossil natural gas, which increases the sustainability of the whole value chain even further.

\section{Engine Operation and Emissions of Lean-Burn Gas Engines}

Especially smaller gas engines are commonly operated under stoichiometric conditions that allow an exhaust gas aftertreatment with the well-established compact three-way catalyst (TWC) [4]. In contrast, lean combustion is frequently preferred for large-bore gas engines, as it maximizes the engine efficiency and additionally contributes to minimizing raw emissions. Under the assumption that a lean-burn natural gas engine consumes $150 \mathrm{~g}$ fuel per $\mathrm{kWh}$ and $\mathrm{CO}_{2}$ is the only greenhouse gas emitted, a greenhouse gas advantage of up to $35 \%$ compared to a diesel engine can be achieved [5]. However, $\mathrm{CO}_{2}$ is not the only component emitted, making a modern and highly efficient aftertreatment system capable of meeting future ultra-low emission limits imperative.

PM, which forms in local areas in the combustion chamber that do not exhibit an ignitable mixture, is only a minor issue. In comparison to diesel and even gasoline engines, natural gas engines emit less PM with overall particle emissions in the magnitude of a diesel engine equipped with a diesel particulate filter (DPF) [6]. Besides, the contact between combustion flame and lube oil used in the engine typically leads to partial combustion of oil, resulting in hydrocarbon and oil ash emissions. Oil ash consists of elements like calcium, magnesium, zinc, phosphorous, or sulfur and is emitted as particulate matter or acts as a catalyst poison [7].

Moreover, the engine's operational point strongly influences the pollutant emissions (Fig. 2). While considerable amounts of $\mathrm{CO}, \mathrm{NO}_{x}$, and hydrocarbons $(\mathrm{HC})$ are emitted during stoichiometric operation, especially $\mathrm{NO}_{x}$ emissions can be minimized by lean operation $[8,9]$, since $\mathrm{NO}_{x}$ mainly forms during a high temperature reaction between oxygen and nitrogen, which is suppressed by the low combustion temperatures during lean operation. In this respect, at least slightly lower $\mathrm{NO}_{x}$ emissions in comparison to diesel engines, which also exhibit low combustion temperatures, are reported [10]. However, tightening environmental legislation will make a dedicated $\mathrm{NO}_{x}$ abatement, i.e., by a system for selective catalytic reduction (SCR) [11], imperative. Hence, despite the lower engine efficiency, the call for stoichiometric operation may grow louder in the future, as additional space-consuming and potentially costly measures for $\mathrm{NO}_{x}$ control will be redundant if a TWC is used for emission control.

Furthermore, partial combustion of methane results in formaldehyde emissions [12]. The recent classification as potentially carcinogenic substance by the European Union (EU) [13] will result in ultra-low emission standards, which can only be met when applying noble metal catalysts, mostly on platinum basis [14]. Since catalytic formaldehyde conversion is a mass transport limited process, optimized catalyst geometries with respect to the channel shape and a homogeneous washcoat distribution are required to overcome low diffusion rates due to the small concentration gradient $[15,16]$.

Amongst the emissions of gas engines, the most important hurdle, however, is methane slip, typically present in the exhaust gas in a magnitude of up to over 3000 ppm, due to incomplete combustion. Methane has a more than 20 times stronger greenhouse potential compared to carbon dioxide, which drastically
Fig. 1 Schematic value chain from production to application for a methane-based energy system

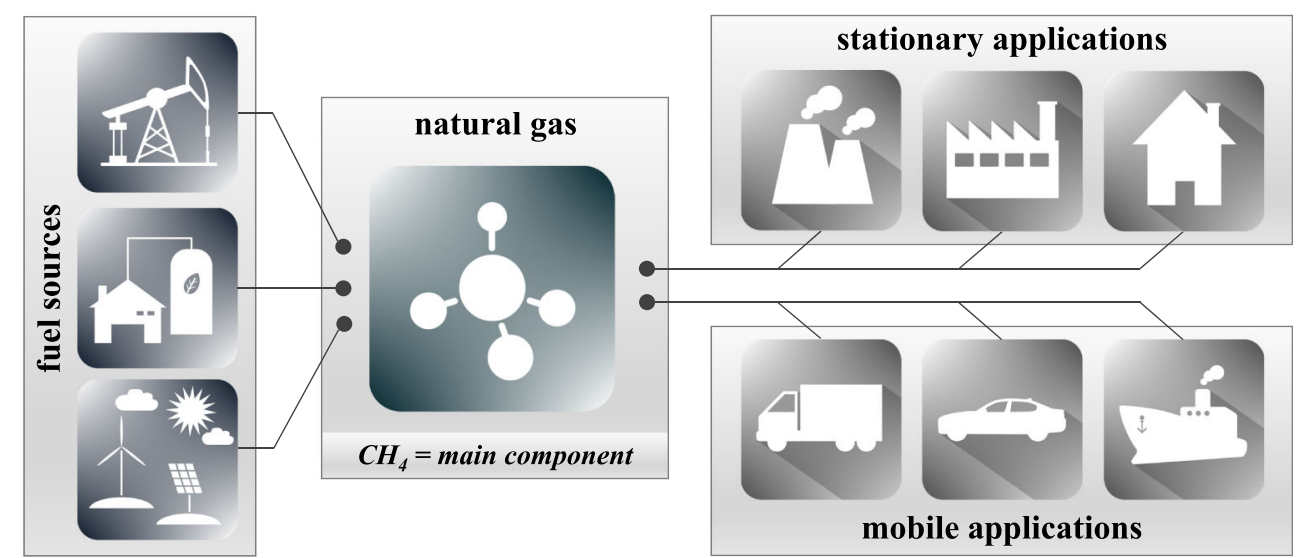




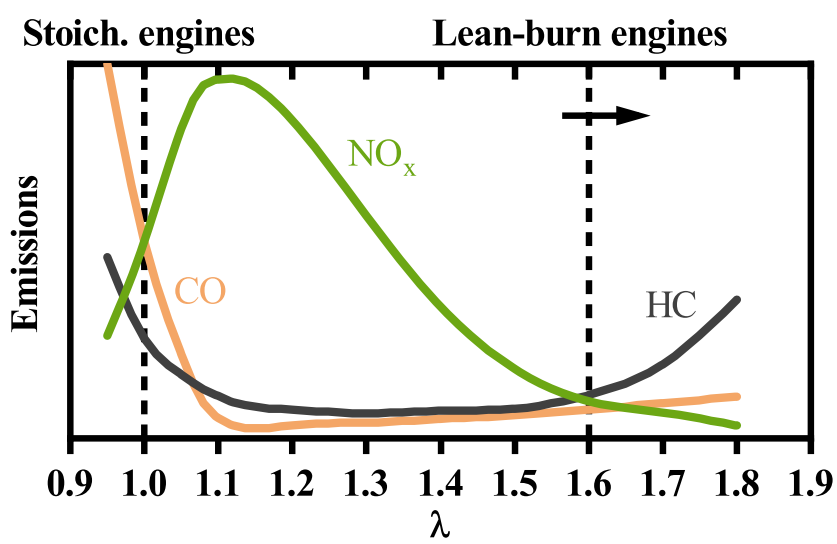

Fig. 2 Emissions of $\mathrm{CO}, \mathrm{HC}$, and $\mathrm{NO}_{x}$ versus lambda (air-to-fuel-ratio). Based on graphs and data from $[8,9]$

reduces the benefit of using gas engines if such amounts of methane are released into the atmosphere. The typically low exhaust gas temperatures impede catalytic combustion of the methane molecule with its high stability and low reactivity, necessitating a highly active catalyst that exhibits excellent stability and durability. In this respect, palladium has been in the focus of scientific interest for decades since it shows the highest activity [17] for catalytic methane conversion.

\section{Methane Oxidation over Palladium: Overcoming Water Inhibition and Sulfur Poisoning}

Despite the initially high activity, palladium catalysts have to cope with two main challenges. Firstly, the inevitable combustion product water, which is also produced by the catalytic methane oxidation reaction itself, leads to pronounced inhibition and continuous deactivation, especially at low temperatures (Fig. 3a). Hydroxyl accumulation on both, the support material and the noble metal, blocks the active sites, which are then unavailable for methane adsorption and conversion [18]. Usage of ceria-based supports with a high oxygen mobility reduces the negative impact of steam, however, this cannot sufficiently redeem the inhibition [19].
Secondly, sulfur compounds $\left(\mathrm{SO}_{x}\right)$ that originate either from the natural gas itself or from deliberately added odorants act as a strong catalyst poison. As shown in Fig. 3b, the presence of only $5 \mathrm{ppm}$ of $\mathrm{SO}_{2}$ in the gas stream already leads to severe catalyst degradation due to poisoning within very short time frames. Poisoning of the palladium phase by $\mathrm{Pd}(\mathrm{SO})_{4}$ formation can lead to a complete loss of activity and support materials such as alumina that form support-related sulfates, hereby acting as a sulfur sink, can only partially protect the noble metal $[20,21]$.

Since the development of materials and catalyst formulations that permanently withstand the negative impact of these species proceeds only slowly, rationally designed process control and reaction engineering approaches pose possible alternatives to ensure high catalytic conversion. Any procedure for catalyst reactivation needs to be an optimized process that takes engine operation and catalyst operation parameters into account, as methane conversion over Pd-based catalysts is particularly sensitive towards the feed gas composition [22]. Rich treatment, for instance, can remove adsorbed surface species blocking the catalyst's active sites, which allows to regenerate catalysts that were deactivated by water or poisoned by sulfur [20, 23, 24]. To avoid a re-poisoning of the noble metal by the remaining supportrelated sulfur species, the reductive treatment should be conducted at elevated temperatures to ensure full regeneration of both, the noble metal and the support material $[25,26]$. The feasibility of reductive pulsing during lean operation for regenerative purposes has not only been demonstrated in the lab, but also in a gas engine operated under realistic conditions. Hereby, the introduction of short reductive phases every $30 \mathrm{~min}$ resulted in a stabilization of methane conversion at approximately $70 \%$, which is considered an adequate level for moderate exhaust gas temperatures of about $4500^{\circ} \mathrm{C}[27]$.

Besides temporary changes of the engine's operational point, also the upstream placement of a three-way catalyst in front of a methane oxidation catalyst was reported to enhance the durability [28]. Finally yet importantly, exploitation of gas-phase chemistry, which is particularly relevant at elevated temperatures and pressures as typically found for pre-turbo applications, may be a step forward. $\mathrm{NO}_{x}$ that is always
Fig. $3 \mathrm{CH}_{4}$ oxidation activity of bimetallic $2.0 \mathrm{wt} \% \mathrm{Pd}-0.4 \mathrm{wt} \%$ Pt catalysts supported on $\mathrm{Al}_{2} \mathrm{O}_{3}$, $\mathrm{CeO}_{2}$, and $\mathrm{CeO}_{2}-\mathrm{ZrO}_{2}$ ("CZ") in (a) $3200 \mathrm{ppm} \mathrm{CH}_{4}, 10 \% \mathrm{O}_{2}$, $0 / 12 \% \mathrm{H}_{2} \mathrm{O}$, and balance $\mathrm{N}_{2}$ during heating with $3{ }^{\circ} \mathrm{C} / \mathrm{min}$; and (b) $3200 \mathrm{ppm} \mathrm{CH}_{4}, 10 \% \mathrm{O}_{2}, 12 \%$ $\mathrm{H}_{2} \mathrm{O}, 5$ ppm $\mathrm{SO}_{2}$, and balance $\mathrm{N}_{2}$ during steady-state operation at $450^{\circ} \mathrm{C}$. GHSV $=80,000 \mathrm{~h}^{-1}$

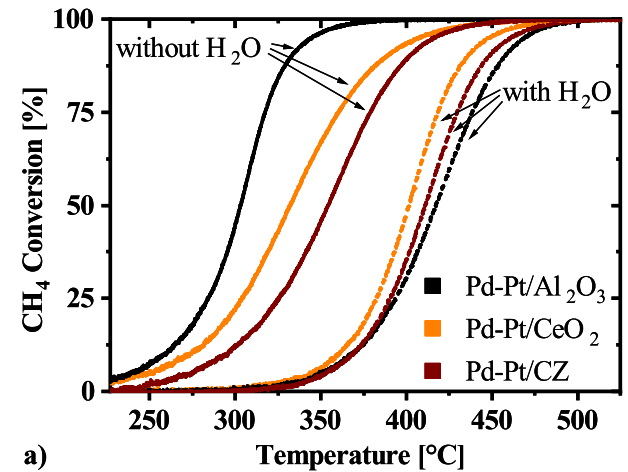

a)

Temperature $\left[{ }^{\circ} \mathrm{C}\right]$

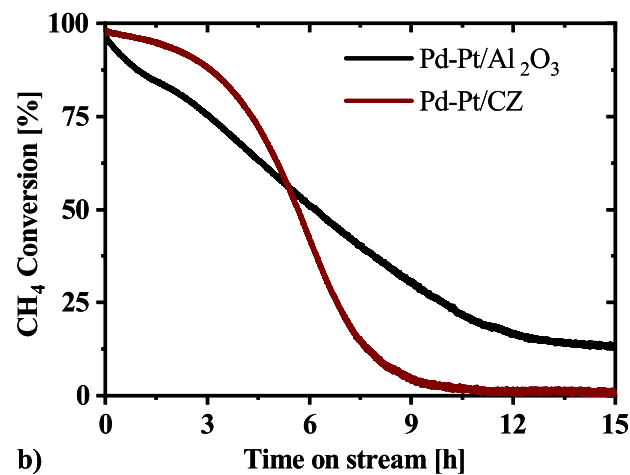

b) 
Fig. 4 Typical engine-out emissions and a possible future design of an exhaust gas aftertreatment system for lean-operated natural gas engines

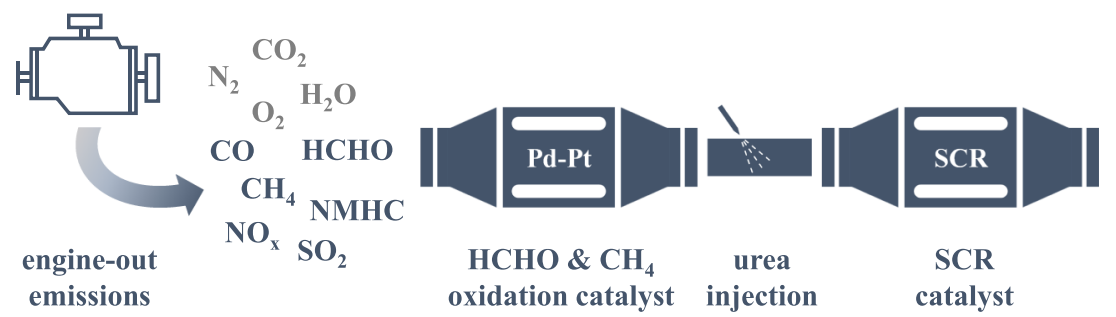

present in the exhaust of gas engines significantly promotes the homogeneous oxidation of light alkanes like methane but also the formation of further HCHO [29]. Therefore, suppressing the formation of undesired side-products and secondary emissions such as $\mathrm{HCHO}$ or $\mathrm{N}_{2} \mathrm{O}$ is another challenge in optimizing the aftertreatment system.

\section{Conclusions and Outlook}

In conclusion, based on a comprehensive fundamental understanding, the combination of different well-established technologies and careful process control can pave the way towards a durable and efficient exhaust gas aftertreatment system for lean-operated natural gas engines. Modern state-of-the-art aftertreatment systems have substantially grown compared to the simple oxidation catalyst originally proposed for emission control by pioneer Eugene J. Houdry [30]. The careful combination of optimally adapted and coordinated measures, i.e. including exhaust gas recirculation, allowed meeting tight emission limits for lean-operated diesel engines in the past [31]. Hence, there is confidence that the remaining technical challenges for meeting forthcoming ultra-low emission standards can similarly be solved for lean-operated natural gas engines, possibly via a system as schematically proposed in Fig. 4. Future exhaust gas aftertreatment systems may be amended by implementing a state-of-the-art urea-based SCR system for $\mathrm{NO}_{x}$ control in addition to the oxidation catalyst. This necessitates a careful choice of both, engine operation parameters for controlling engine-out emissions and catalyst formulation for minimizing secondary emissions, for instance since $\mathrm{HCHO}$ and $\mathrm{NH}_{3}$ can form highly toxic $\mathrm{HCN}$ over several SCR catalysts $[32,33]$. However, as this approach is already well-established in the context of lean-burn diesel engines, the technological hurdles for extending the overall system are expected to be moderate, allowing a fast realization and transfer into serial production. Entirely novel approaches as utilization of non-linear flow channels may further contribute to finding a holistic solution [34].

Looking forward, the widespread use of natural gas engines is not only a scientific-technical issue, but also a political one. Although many countries strive for an electrification of the onroad sector, combustion engines will remain indispensable at least in stationary and heavy-duty applications in the near future. This may lead to a more diverse global energy system where natural gas engines can play an important role. In this context, an efficient exhaust gas aftertreatment system for lean-operated natural gas engines is essential for ecological and economic competitiveness. Particularly, the recent progress on catalyst operation, activation, and regeneration strategies is encouraging and allows optimism that natural gas engines can significantly contribute to reducing mankind's carbon footprint.

Acknowledgments We gratefully acknowledge our former and present colleagues at KIT, who significantly contributed to the research on emission control of gas engines and hereby brought this topic forward. In particular, we thank Dr. M. Casapu and Prof. Dr. J.-D. Grunwaldt for many years of fruitful scientific discussion and outstanding collaboration. Equally important, we express our sincere gratitude to many national and international partners from academia and industry that supported our work with financial resources and invaluable expertise.

Funding Open Access funding enabled and organized by Projekt DEAL.

Code Availability Not applicable

Data Availability All data can be obtained from the authors upon reasonable request.

\section{Compliance with Ethical Standards}

Competing Interests The authors declare that they have no competing interests.

Open Access This article is licensed under a Creative Commons Attribution 4.0 International License, which permits use, sharing, adaptation, distribution and reproduction in any medium or format, as long as you give appropriate credit to the original author(s) and the source, provide a link to the Creative Commons licence, and indicate if changes were made. The images or other third party material in this article are included in the article's Creative Commons licence, unless indicated otherwise in a credit line to the material. If material is not included in the article's Creative Commons licence and your intended use is not permitted by statutory regulation or exceeds the permitted use, you will need to obtain permission directly from the copyright holder. To view a copy of this licence, visit http://creativecommons.org/licenses/by/4.0/.

\section{References}

1. The European Parliament and the Council of the European Union: Regulation (EU) No 2019/63. Official Journal of the European Union (2019). http://data.europa.eu/eli/dec/2019/63/oj

2. Environmental Protection Agency (EPA) and Department of Transportation: 2017 and Later Model Year Light-Duty Vehicle Greenhouse Gas Emissions and Corporate Average Fuel 
Economy Standards. Federal Register - The Daily Journal of the United States Government (2012). https://www.govinfo.gov/ content/pkg/FR-2012-10-15/pdf/2012-21972.pdf

3. International Energy Agency (IEA): Natural Gas Information 2019 (2019). https://doi.org/10.1787/4d2f3232-en

4. Bounechada, D., Groppi, G., Forzatti, P., Kallinen, K., Kinnunen, T.: Effect of periodic lean/rich switch on methane conversion over a Ce- $\mathrm{Zr}$ promoted $\mathrm{Pd}-\mathrm{Rh} / \mathrm{Al}_{2} \mathrm{O}_{3}$ catalyst in the exhausts of natural gas vehicles. Appl. Catal. B. 119-120, 91-99 (2012). https://doi.org/10. 1016/j.apcatb.2012.02.025

5. Horgen, O.M.: Rolls-Royce Marine - the "Environship Concept". System Solutions \& Wave Piercing Technology in SNAME GL\&GR Meeting, Cleveland (2012)

6. Hesterberg, T.W., Lapin, C.A., Bunn, W.B.: A comparison of emissions from vehicles fueled with diesel or compressed natural gas. Environ. Sci. Technol. 42(17), 6437-6445 (2008). https://doi.org/ 10.1021/es071718i

7. Givens, W. A., Buck, W. H., Jackson, A., Kaldor, A., Hertzberg, A., Moehrmann, W., Mueller-Lunz, S., Pelz, N., Wenninger, G.: Lube formulation effects on transfer of elements to exhaust aftertreatment system components. SAE Technical Paper 2003-01-3109 (2003). https://doi.org/10.4271/2003-01-3109

8. Herdin, G. R.: Standesanalyse des Gasmotors im Vergleich zu den Zukunftstechniken (Brennstoffzellen und Mikroturbine) bei der Nutzung von aus Biomasse gewonnenen Kraftstoffen. http:// images.energieportal24.de/dateien/downloads/gasmotorenanalyse.pdf.

9. Seiffert, U., Walzer, P.: Chapter seven - future trends in engine technology. In: Arcoumanis, C. (ed.) Internal Combustion Engines, pp. 339-394. Academic Press Limited, London (1988). https://doi.org/10.1016/B978-0-12-059790-1.50013-4

10. Ayala, A., Kado, N. Y., Okamoto, R. A., Holmen, B. A., Kuzmicky, P. A., Kobayashi, R., Stiglitz, K. E.: Diesel and CNG heavy-duty transit bus emissions over multiple driving schedules: regulated pollutants and project overview. SAE Technical Paper 2002-01-1722 (2002). https://doi.org/10.4271/2002-01-1722

11. Deutschmann, O., Konstandopoulos, A.G.: Chapter 18 - catalytic technology for soot and gaseous pollution control. In: Lackner, M., Winter, F., Agarwal, A. (eds.) Handbook of Combustion Part 2: Combustion Diagnostics and Pollutants, pp. 465-510. WileyVCH Verlag, Weinheim (2010). https://doi.org/10.1002/ 9783527628148.hoc 038

12. Mitchell, C.E., Olsen, D.B.: Formaldehyde formation in large bore natural gas engines part 1: formation mechanisms. J. Eng. Gas Turbines Power. 122(4), 603-610 (2000). https://doi.org/10.1115/ 1.1290585

13. The European Parliament and the Council of the European Union: Commission Regulation (EU) No 605/2014. Official Journal of the European Union (2014). http://data.europa.eu/eli/reg/2014/605/oj

14. Gremminger, A., Pihl, J., Casapu, M., Grunwaldt, J.D., Toops, T.J., Deutschmann, O.: PGM based catalysts for exhaust-gas after-treatment under typical diesel, gasoline and gas engine conditions with focus on methane and formaldehyde oxidation. Appl. Catal. B. 265, 118571 (2020). https://doi.org/10.1016/j.apcatb.2019.118571

15. Torkashvand, B., Maier, L., Lott, P., Schedlbauer, T., Grunwaldt, J.-D., Deutschmann, O.: Formaldehyde oxidation over platinum: on the kinetics relevant to exhaust conditions of lean-burn natural gas engines. Top. Catal. 62(1-4), 206-213 (2019). https://doi.org/10. 1007/s11244-018-1087-y

16. Torkashvand, B., Maier, L., Hettel, M., Schedlbauer, T., Grunwaldt, J.-D., Deutschmann, O.: On the challenges and constrains of ultra-low emission limits: formaldehyde oxidation in catalytic sinusoidal-shaped channels. Chem. Eng. Sci. 195, 841-850 (2019). https://doi.org/10.1016/j.ces.2018.10.031

17. Gelin, P., Primet, M.: Complete oxidation of methane at low temperature over noble metal based catalysts: a review. Appl. Catal. B.
39(1), 1-37 (2002). https://doi.org/10.1016/S0926-3373(02) 00076-0

18. Ciuparu, D., Perkins, E., Pfefferle, L.: In situ DR-FTIR investigation of surface hydroxyls on $\gamma-\mathrm{Al}_{2} \mathrm{O}_{3}$ supported $\mathrm{PdO}$ catalysts during methane combustion. Appl. Catal. A. 263(2), 145-153 (2004). https://doi.org/10.1016/j.apcata.2003.12.006

19. Cargnello, M., Delgado Jaén, J.J., Hernández Garrido, J.C., Bakhmutsky, K., Montini, T., Calvino Gámez, J.J., Gorte, R.J., Fornasiero, P.: Exceptional activity for methane combustion over modular $\mathrm{Pd} @ \mathrm{CeO}_{2}$ subunits on functionalized $\mathrm{Al}_{2} \mathrm{O}_{3}$. Science. 337(6095), 713-717 (2012). https://doi.org/10.1126/science. 1222887

20. Hoyos, L.J., Praliaud, H., Primet, M.: Catalytic combustion of methane over palladium supported on alumina and silica in presence of hydrogen sulfide. Appl. Catal. A. 98(2), 125-138 (1993). https://doi.org/10.1016/0926-860X(93)80028-O

21. Mowery, D.L., McCormick, R.L.: Deactivation of alumina supported and unsupported PdO methane oxidation catalyst: the effect of water on sulfate poisoning. Appl. Catal. B. 34(4), 287-297 (2001). https://doi.org/10.1016/S0926-3373(01)00222-3

22. Bugosh, G.D., Easterling, V.G., Rusakova, I.A., Harold, M.P.: Anomalous steady-state and spatio-temporal features of methane oxidation on $\mathrm{Pt} / \mathrm{Pd} / \mathrm{Al}_{2} \mathrm{O}_{3}$ monolith spanning lean and rich conditions. Appl. Catal. B. 165, 68-78 (2015). https://doi.org/10.1016/j. apcatb.2014.09.058

23. Arosio, F., Colussi, S., Groppi, G., Trovarelli, A.: Regeneration of S-poisoned $\mathrm{Pd} / \mathrm{Al}_{2} \mathrm{O}_{3}$ catalysts for the combustion of methane. Catal. Today. 117(4), 569-576 (2006). https://doi.org/10.1016/j. cattod.2006.06.006

24. Karinshak, K.A., Lott, P., Harold, M.P., Deutschmann, O.: In situ activation of bimetallic Pd-Pt methane oxidation catalysts. ChemCatChem. 12(14), 3712-3720 (2020). https://doi.org/10. $1002 /$ cctc. 202000603

25. Honkanen, M., Wang, J., Kärkkäinen, M., Huuhtanen, M., Jiang, H., Kallinen, K., Keiski, R.L., Akola, J., Vippola, M.: Regeneration of sulfur-poisoned Pd-based catalyst for natural gas oxidation. J. Catal. 358, 253-225 (2018). https://doi.org/10.1016/j.jcat.2017. 12.021

26. Lott, P., Eck, M., Doronkin, D.E., Zimina, A., Tischer, S., Popescu, R., Belin, S., Briois, V., Casapu, M., Grunwaldt, J.-D., Deutschmann, O.: Understanding sulfur poisoning of bimetallic Pd-Pt methane oxidation catalysts and their regeneration. Appl. Catal. B. 278, 119244 (2020). https://doi.org/10.1016/j.apcatb. 2020.119244

27. Gremminger, A., Lott, P., Merts, M., Casapu, M., Grunwaldt, J.-D., Deutschmann, O.: Sulfur poisoning and regeneration of bimetallic Pd-Pt methane oxidation catalysts. Appl. Catal. B. 218, 833-843 (2017). https://doi.org/10.1016/j.apcatb.2017.06.048

28. Kinnunen, N.M., Keenan, M., Kallinen, K., Maunula, T., Suvanto, M.: Engineered sulfur-resistant catalyst system with an assisted regeneration strategy for lean-burn methane combustion. ChemCatChem. 10(7), 1556-1560 (2018). https://doi.org/10. $1002 /$ cctc. 201701884

29. Torkashvand, B., Lott, P., Zengel, D., Maier, L., Hettel, M., Grunwaldt, J.-D., Deutschmann, O.: Homogeneous oxidation of light alkanes in the exhaust of turbocharged lean-burn gas engines. Chem. Eng. J. 377, 119800 (2019). https://doi.org/10.1016/j.cej. 2018.08.186

30. Houdry, E. J.: Catalytic structure and composition. U.S. Patent 2, 742,437, April 17, 1956

31. Konstandopoulos, A.G., Kostoglou, M., Beatrice, C., Di Blasio, G., Imren, A., Denbratt, I.: Impact of combination of EGR, SCR, and DPF Technologies for the low-emission rail diesel engines. Emiss. Control Sci. Technol. 1(3), 213-225 (2015). https://doi.org/10. 1007/s40825-015-0020-0 
32. Zengel, D., Koch, P., Torkashvand, B., Grunwaldt, J.-D., Casapu, M., Deutschmann, O.: Emission of toxic $\mathrm{HCN}$ during $\mathrm{NO}_{\mathrm{x}}$ removal by ammonia SCR in the exhaust of lean-burn natural gas engines. Angew. Chem. Int. Ed. 59(34), 14423-14428 (2020). https://doi. org/10.1002/anie.202003670

33. Elsener, M., Nuguid, R.J.G., Kröcher, O., Ferri, D.: HCN production from formaldehyde during the selective catalytic reduction of
$\mathrm{NO}_{\mathrm{x}}$ with $\mathrm{NH}_{3}$ over $\mathrm{V}_{2} \mathrm{O}_{5} / \mathrm{WO}_{3}-\mathrm{TiO}_{2}$. Appl. Catal. B. 281, 119462 (2020). https://doi.org/10.1016/j.apcatb.2020.119462

34. Masoudi, M.: Catalytic converters having non-linear flow channels. U.S. Patent 10,598,068, March 24, 2020

Publisher's Note Springer Nature remains neutral with regard to jurisdictional claims in published maps and institutional affiliations. 